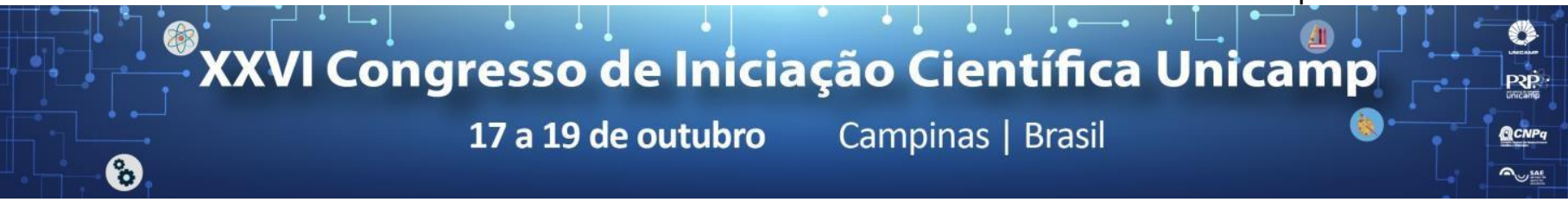

\title{
Determinação do papel dos cementócitos na homeostasia do cemento dental.
}

\author{
Luana A. Pitton*, Cristiane R. Salmon, Elis J. L. dos Santos, Francisco H. N. Júnior.
}

\section{Resumo}

Os cementócitos dividem características morfológicas com os osteócitos e expressam, em comum, inúmeros reguladores do metabolismo tecidual. Entretanto o papel dos cementócitos na homeostasia do cemento dental não está esclarecido. Assim, a hipótese da presente investigação foi de que os cementócitos desempenham um papel importante na manutenção do periodonto de sustentação. Alterações morfológicas e ultraestruturais nestas células foram observadas por microscopia eletrônica de transmissão e confocal, como evidências de sua participação no controle da homeostasia do cemento dental utilizando-se um modelo experimental de aposição contínua do cemento dental celular.

\section{Palavras-chave:}

Cementócitos, cemento dental, homeostasia.

\section{Introdução}

O cemento dental (CD) é um tecido mineralizado, composto por cementoblastos e cementócitos, que cobre a superfície radicular do dente e promove por meio do ligamento periodontal (LP), a inserção deste no osso alveolar (OA) [1, 2]. Apesar do conhecimento a nível celular e molecular deste tecido ser pouco definido [3], características morfológicas e biológicas comuns para osteócitos e cementócitos, além das similaridades entre a matriz do tecido ósseo e do cemento dental, indicam que os cementócitos possam exercer um papel significativo para a manutenção do cemento dental, bem como de todo o conjunto que compõe o periodonto de sustentação. Desta forma, o presente estudo foi realizado com 0 objetivo de se identificar alterações estruturais em cementócitos durante o processo de aposição do cemento dental indicativos de atividade celular.

\section{Resultados e Discussão}

Neste estudo foi utilizado o modelo experimental de erupção dental continuada, com consequente estímulo para formação de cemento dental celular [4]. Os resultados obtidos a partir dos dados coletados indicam que o cemento dental celular apresentou aumento em sua área; e alterações ultraestruturais que incluem aumento do volume nuclear e celular, e a condensação da cromatina sugerem que os cementócitos têm papel ativo na homeostasia do cemento dental.

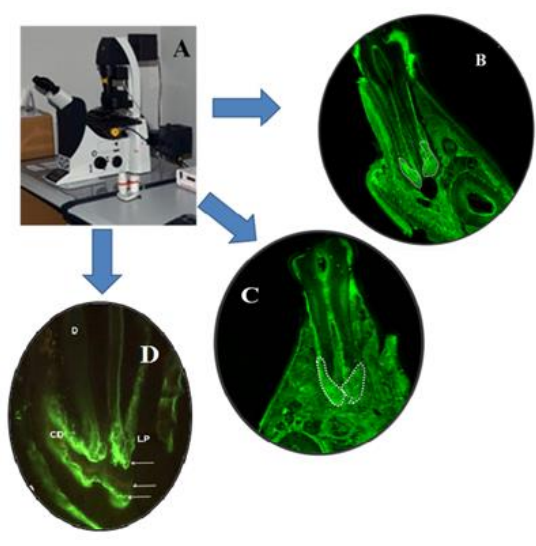

Figura 1. A imagem mostra as áreas de cemento celular marcadas com fluorosceína isotiocianato presente nos grupos controle (B) e teste (C). O grupo teste apresenta maior área de cemento. A imagem $\mathbf{D}$ exibe as linhas de aposição de cemento de uma amostra corada com calceína e tetraciclina.

Figura 2. Revela a ultraestrutura celular dos cementócitos (Ccy) e cementoblastos (Cmb).

Os cementoblastos possuem núcleo bem definido e extenso, além de um abundante citoplasma com RER e numerosos ribossomos (B, E). No grupo teste, o retículo endoplasmático destas células é mais desenvolvido (B, D); Cementócitos do grupo teste possuíam volume celular e nuclear

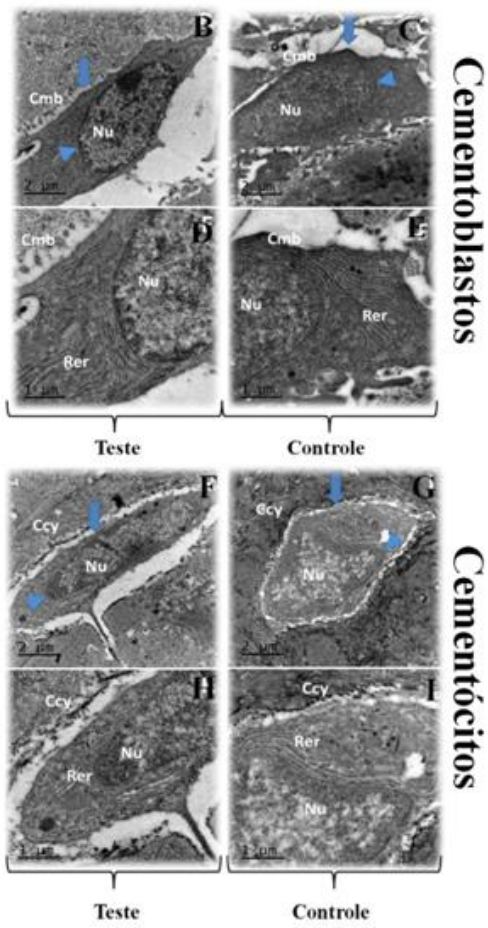
aumentados, além de cromatina periférica mais condensada $(\mathbf{F}, \mathrm{H})$.

\section{Conclusões}

Os achados morfológicos e ultraestruturais sugerem que os cementócitos desempenham um papel importante no controle da aposição experimental da matriz do cemento dental formado.

Agradecimentos
Agradeço ao PIBIC pela concessão da bolsa.

${ }^{1}$ Bosshardt DD, Selvig KA. Dental cementum: the dynamic tissue covering of the root. Periodontol 2000. 1997;13:41-75.

${ }^{2}$ Foster BL, Somerman MJ. Cementum. In: McCauley LK, Somerman MJ, editors. Mineralized Tissues in Oral and

Craniofacial Science: Biological Principles and Clinical Correlates. 1st ed. Ames, IA: Wiley-Blackwell; 2012. p. 169-92.

${ }^{3}$ Saygin NE, Giannobile WV, Somerman MJ. Molecular and cell biology of cementum. Periodontol 2000. 2000;24:73-98.

${ }^{4}$ Luan X, Ito Y, Holliday S, Walker C, Daniel J, Galang TM, et al. Extracellular matrix-mediated tissue remodeling following axial movement of teeth. J Histochem Cytochem.2007;55(2):127-4. 